\title{
PENGGUNAAN GADGET DALAM PAK UNTUK MEMPERDALAM KEROHANIAN PESERTA DIDIK
}

\author{
Yani Margaretha Molawan, Ermin Alperiana Mosooli \\ Sekolah Tinggi Teologi Star's Lub Luwuk Banggai \\ yanimargaretha520@gmail.com
}

\begin{abstract}
Gadgets are one of the tools favored by teenagers. Besides having some negative influences, the device also has many positive benefits for teens. One of them can be used to deepen teenage spirituality. But for that, they need assistance. Christian Education (CE) in schools is one of the potential assistance systems. This study aims to determine the extent to which students at school use gadgets to deepen spirituality and how CE in schools affects the use of these gadgets. The research method used is a quantitative and qualitative mixed method. The study was conducted in two stages. The first stage was quantitative research with the subjects of Luwuk Christian Junor High School Students, Banggai, Central Sulawesi. The number of respondents was eighty-sixed students with forty-eight samples. The results obtained, students in Luwuk Christian Junor High School rarely use gadgets to deepen their spirituality. The second phase of research is qualitative research. Data collection techniques included interviews with a single CE teacher who taught at the school and document studies of the 2013 Curriculum as well as the primary CE textbooks used at school. The results obtained, the material about gadgets in PAK has not been significant. The portion of gadgets is still small in the curriculum. There are no textbooks in schools that specifically discuss $C E$ and gadgets. CE teacher has not played a strategic role. Conclusion: CE in Luwuk Christian Junior High School has not yet conditioned students to use gadgets to deepen their spirituality.
\end{abstract}

Keywords: gadget, teenage spirituality, Christian Education, Curriculum, Luwuk Christian Junior High School

\begin{abstract}
Abstrak. Gadget merupakan salah satu alat yang digemari para remaja. Selain memiliki sejumlah pengaruh negatif, gadget juga memiliki sejumlah manfaat positif bagi remaja. Salah satunya bisa digunakan untuk memperdalam kerohanian remaja. Namun untuk itu diperlukan pendampingan. Pendidikan Agama Kristen (PAK) di sekolah merupakan salah satu sistem pendampingan yang potensial. Penelitian ini bertujuan untuk mengetahui sejauhmana para peserta didik di sekolah menggunakan gadget untuk memperdalam kerohanian, dan bagaimana PAK di sekolah berpengaruh terhadap penggunaan gadget tersebut. Metode penelitian yang digunakan adalah metode campuran (mix method) kuantitatif dan kualitatif. Penelitian dilakukan dua tahap. Tahap pertama adalah penelitian kuantitatif dengan subyek Siswa SMP Kristen Luwuk, Banggai, Sulawesi Tengah. Jumlah responden delapan puluh enam siswa dengan empat puluh delapan sampel. Hasil yang diperoleh, peserta didik di SMP Kristen Luwuk jarang menggunakan gadget untuk memperdalam kerohanian mereka. Penelitian tahap kedua adalah penelitian kualitatif. Tehnik pengambilan data berupa wawancara dengan informan tunggal guru PAK yang mengajar di sekolah tersebut dan studi dokumen terhadap Kurikulum 2013 serta buku-buku pelajaran utama PAK yang digunakan di sekolah. Hasil yang diperoleh, materi mengenai gadget dalam PAK belum signifikan. Porsi gadget masih sedikit dalam kurikulum, belum ada buku-buku materi pelajaran di sekolah yang khusus membahas tentang PAK dan gadget, guru PAK belum memainkan peran strategis. Kesimpulan: PAK di SMP Kristen Luwuk belum terlalu mengkondisikan peserta didik menggunakan gadget untuk memperdalam kerohanian mereka.
\end{abstract}


Kata Kunci: gadget, kerohanian remaja, Pendidikan Agama Kristen, kurikulum, SMP Kristen Luwuk

\section{PENDAHULUAN}

Masa remaja adalah masa transisi perkembangan dari masa kanak-kanak menuju dewasa. Seperti dikatakan Saputro, pada masa ini, seseorang biasa menghadapi masa-masa sulit karena berkembangnya perilaku-perilaku khusus seperti: 1) mulai menyampaikan kebebasan dan haknya berpendapat sendiri yang bisa menimbulkan ketegangan dan perselisihan dengan keluarga, 2) mulai dipengaruhi teman-teman sebaya yang bisa menurunkan pengaruh orang tua, 3) mengalami kebingungan, ketakutan, frutrasi dan rasa bersalah sebagai dampak dari pertumbuhan fisik yang pesat, termasuk seksualitas, 4) terlalu percaya diri yang mengakibatkannya sulit menerima nasihat orang tua. (Saputro 2018).

Dengan demikian masa remaja perlu diisi dengan hal-hal yang positif. Pailang dan Palar mengatakan bila masa ini dilewati dengan kegagalan maka sangat mungkin akan gagal dalam perjalanan kehidupan selanjutnya. Sebaliknya bila diisi dengan kesuksesan, maka sangat mungkin akan sukses setelah dewasa nanti. (Pailang dan Palar 2012). Sebab itu remaja perlu mendapatkan pendampingan dari pihak lain.

Bagi umat Kristen, salah satu bentuk konkrit pendampingan remaja adalah melalui Pendidikan Agama Kristen (PAK), baik di gereja, di keluarga, maupun di sekolah. Sebab, seperti dikatakan Gultom, PAK merupakan usaha yang dilakukan secara sadar dan terencana dan kontinyu untuk mengembangkan kemampuan peserta didik dalam memahami dan menghayati kasih Allah dalam Yesus Kristus 
yang dinyatakan dalam kehidupan sehari-hari terhadap sesama dan lingkungan. (Gultom 2008). PAK adalah suatu bentuk pendampingan terhadap remaja yang tersistem dan menghubungkan iman Kristen dengan kehidupan sehari-hari yang dijalani oleh para remaja. Dengan begitu potensinya cukup signifikan dalam mengarahkan remaja menjalani kehidupan yang positif.

Khusus mengenai PAK di sekolah, Posumah-Santoso mengatakan, tujuannya bukan hanya sekedar pengenalan dan pengetahuan tentang agama, melainkan agar peserta didik beriman kepada Tuhan bahkan mencapai pribadi yang dewasa dan utuh. (Posumah-Santoso 2006). Ini bermakna PAK di sekolah mestinya lebih mengarah pada pengembangan karakter, pada kemampuan mereka untuk menghadapi realita kehidupan secara positif berdasarkan nilai-nilai Kristen.

Salah satu tantangan yang dihadapi remaja di masa kini adalah kehadiran gadget, yaitu alat elektronik kecil dengan berbagai macam fungsi ini yang dapat berupa komputer atau laptop, tablet, dan juga telepon seluler (Marpaung 2018) biasa difungsikan untuk komunikasi, belajar, dan hiburan. (Chusna 2017).

Alat ini sangat diminati juga karena kemampuannya terhubung dengan internet. Hasil suvey nasional yang dilakukan oleh Asosiasi Penyelenggara Jasa Internet Indonesia (APJII) tahun 2018 menunjukkan bahwa pengguna internet di Indonesia melakukan koneksi internet melalui gadget, yaitu komputer atau laptop, smartphone, dan tablet. (APJII 2018).

Remaja merupakan kelompok umur dengan tingkat penggunaan internet yang cukup tinggi. Dari data survey nasional APJII tahun 2018, 91\% responden yang berusia 15-19 tahun dan 66,2 yang berusia 10-14 tahun adalah pengguna 
internet. Begitu juga, 80,4\% yang sedang sekolah SMP serta, 90,2\% yang sedang sekolah SMA merupakan pengguna internet. (APJII 2018). Jika dikaitkan dengan lokasi perdesaan dan perkotaan, ternyata pengguna internet bukan hanya masyarakat kota, tapi juga sudah merambah masyarakat pedesaan. Dari data survey APJII 2018, jika 74,1\% responden kota mengaku sebagai pengguna internet, maka $61,6 \%$ dari responden pedesaan mengaku juga sudah terbiasa menggunakan internet. (APJII 2018). Ini mengindikasikan bahwa bukan hanya remaja di kota yang umumnya terbiasa dengan internet, tapi juga remaja di perdesaan.

Hal menarik lain dari data survey tersebut, ternyata media sosial merupakan salah satu alasan penting para responden menggunakan internet. Media sosial menempati urutan kedua $(18,9 \%)$ setelah komunikasi lewat pesan $(24,7 \%)$ sebagai alasan utama mereka menggunakan internet. Lebih menarik lagi, ternyata media sosial menjadi alasan kedua tertinggi $(19,1 \%)$ selain komunikasi lewat pesan $(16,4 \%)$, dan mengisi waktu luang $(15,2 \%)$. Konten media sosial yang paling sering dikunjungi adalah facebook (57,7\%), menyusul Instagram $(17,8 \%)$, dan YouTube $(15,1 \%)$. (APJII 2018). Kesimpulan yang bisa ditarik dari data tersebut adalah bahwa remaja di Indonesia merupakan salah satu kelompok pengguna media sosial yang aktif.

Fakta ini dapat saja dinilai negatif mengingat media sosial memang membawa sejumlah hal negatif bagi remaja sebagaimana hasil riset berikut. Juwita dkk, dalam penelitian mereka terhadap pengaruh media sosial terhadap gaya hidup remaja di SMA Negeri 5 Bandung menemukan sejumlah dampak 
BONAFIDE: Jurnal Teologi dan Pendidikan Kristen

www.jurnal.sttissiau.ac.id/Volume 1/Nomor 1/Juni 2020/hal. 83-101

negatif media sosial terhadap responden, antara lain "munculnya sikap individualistis, kurang peka terhadap lingkungan, ingin mendapatkan segala sesuatu dengan instan, sikap konsumtif, serta adanya anggapan media sosial sebagai ukuran gaul atau tidaknya seseorang." (Juwita, Budimansyah, dan Nurbayani 2015, 3-4). Media sosial juga memunculkan masalah baru yaitu hoax, cyber-hate dan cyber-bullying. (Anwar 2017).

Meskipun demikian, dari sisi Pendidikan Agama Kristen, fenomena ini ada baiknya juga direspon secara positif. Selain konten-konten negatif yang ada di media sosial, di sana juga terdapat banyak konten-konten rohani seperti ayat-ayat Alkitab, kisah-kisah rohani inspiratif, lagu-lagu rohani, video rohani, grup-grup dan halaman-halaman rohani, dll. Semuanya ini mestinya memberi pengaruh positif bagi peningkatan kualitas rohani orang Kristen, termasuk para remaja, apabila sering diakses atau diikuti dengan baik. Namun sebagaimana hasil riset Tani, dkk, terhadap peran media online terhadap pemuda Gereja Advent di Walantakan Kecamatan Langowan Barat mereka lebih banyak menggunakan media sosial untuk pertemanan dan hiburan dibandingkan untuk menunjang iman mereka. (Tani, Boham, dan Tangkudung 2016).

Artinya, gadget dalam kaitan dengan internet dan media sosial sebenarnya bisa memberi manfaat positif bagi pertumbuhan iman para remaja, hanya saja perlu diarahkan secara khusus. Di sinilah PAK bisa memainkan peran aktif dalam mendorong para remaja agar menggunakan gadget untuk memperdalam kerohanian mereka. Pertanyaannya, apakah PAK yang dilaksanakan, khususnya di 
sekolah, sudah mengintegrasikan gadget dalam proses pembelajaran dan memberi pengaruh kepada penggunaan gadget di kalangan peserta didik?

Hal ini menarik untuk diteliti dalam rangka memberi masukan kepada penyelenggaraan PAK di sekolah-sekolah yang merupakan tempat pendidikan anak-anak remaja Kristen. Untuk itu penulis melakukan penelitian di SMP Kristen di kota Luwuk, kabupaten Banggai, Propinsi Sulawesi Tengah. Penelitian dilakukan pada bulan Maret-April 2019. Tujuan penelitian adalah mengetahui sejauh manakah PAK di SMP Kristen Luwuk memberi pengaruh kepada penggunaan gadget peserta didik untuk memperdalam kerohanian mereka.

\section{METODE PENELITIAN}

Penelitian ini menggunakan metode campuran (mix method) kuantitatif dan kualitatif. Menurut Sugiyono, metode kuantitatif adalah metode penelitian yang data penelitiannya berupa angka-angka dan dianalisis menggunakan statistik. Sedangkan metode kualitatif adalah metode penelitian yang dan analisisnya lebih bersifat kualitatif. Kedua metode ini dapat digabungkan, dilakukan secara bersama-sama dalam suatu penelitian agar diperoleh data yang lebih komprehensif, valid, reliabel, dan obyektif. (Sugiyono 2015). Strategi metode campuran yang digunakan adalah strategi bertahap, khususnya strategi bertahap eksploratis. Pada tahap pertama, penelitian dilakukan dengan metode kuantatif lalu dilanjutkan tahap kedua dengan metode kualitatif. Bobot utama diberikan kepada metode kuantitatif. (Creswell 2016).

Pada tahap pertama yang diteliti adalah tingkat peggunaan gadget di kalangan peserta didik untuk memperdalam kerohanian mereka. Data diambil 
dengan kuesioner dengan menggunakan skala Likert. Seperti dikemukakan Sugiyono, skala Likert digunakan untuk mengukur sikap, pendapat dan persepsi seseorang atau sekelompok orang tentang suatu fenomena sosial dengan plihan jawaban: SL (selalu), SRG (sering), JRG (jarang), dan TP (tidak pernah). (Sugiyono 2018).

Ada lima indikator yang digunakan untuk mengukur tindakan peserta didik menggunakan gadget dalam rangka memperdalam kerohanian, yaitu: 1) membaca Alkitab di smartphone, 2) mendengarkan lagu-lagu rohani di smartphone, 3) menggunakan gadget untuk mencari materi renungan di internet, 4) membaca status-status rohani di media sosial, 5) mengikuti akun-akun rohani di media sosial.

Hipotesis yang diajukan adalah hipotesis deskriptif:

H0 : Peserta didik di SMP Kristen Luwuk TIDAK SERING menggunakan gadget untuk memperdalam kerohanian mereka.

H1 : Peserta didik di SMP Kristen Luwuk SERING menggunakan gadget untuk memperdalam kerohanian mereka.

Populasi dalam penelitian ini adalah semua peserta didik SMP Kristen Luwuk yang sedang duduk di kelas VII, VIII, dan IX dengan jumlah 86 orang. Sampel diambil dengan tehnik acak sederhana (simple random sampling) yang, menurut Sugiyono, memberi kesempatan yang sama pada setiap anggota populasi untuk dipilih sebagai sampel. (Sugiyono 2015). Hasilnya, 46 peserta didik terpilih sebagai sampel. 
Penelitian tahap kedua menggunakan metode kualitatif untuk mengetahui penggunaan gadget pelaksanaan pembelajaran PAK di SMP Kristen Luwuk. Data yang hendak diperoleh adalah perspektif guru PAK di sekolah mengenai hal tersebut didukung dengan analisa dokumen terhadap kurikulum yang dan bukubuku PAK yang digunakan. Data ini akan digunakan untuk menilai dan menjelaskan tingkat penggunaan gadget di kalangan peserta didik untuk memperdalam kerohanian mereka.

Asumsinya, jika penggunaan gadget masuk dalam pembelajaran PAK, maka peserta didik akan sering menggunakan gadget untuk memperdalam kerohanian mereka. Sebaliknya, jika penggunaan gadget tidak masuk dalam pembelajaran PAK maka peserta didik tidak sering menggunakan gadget untuk memperdalam kerohanian mereka.

\section{HASIL}

\section{Penggunaan Gadget Peserta Didik untuk Memperdalam Kerohanian}

Tabel 1. Hasil Uji Hipotesis

\begin{tabular}{|l|r|}
\hline & Penggunaan Gadget \\
\hline Mann-Whitney U & 209,500 \\
Wilcoxon W & 485,500 \\
Z & $-1,211$ \\
Asymp. Sig. (2-tailed) &, 226 \\
\hline
\end{tabular}

Hipotesis H1 yang diajukan dalam penelitian tahap 1 adalah "Peserta didik di SMP Kristen Luwuk SERING menggunakan gadget untuk memperdalam $\begin{array}{lr}\text { Yani Margaretha Molawan, Ermin Alperiana Mosooli } & 90\end{array}$ 
kerohanian mereka”. Dasar pengambilan keputusan yang dijadikan acuan dalam uji ini adalah jika nilai signifikansi atau asymp.sig lebih kecil dari probabilitas 0,05, maka hipotesis $\mathrm{H} 1$ diterima. Namun jika nilai asymp.sig lebih besar dari probabilitas 0,05 , maka hipotesis $\mathrm{H} 1$ ditolak. Dari tabel di atas tampak bahwa nilai asymp.sig sebesar 0,226 yang berarti lebih besar dari 0,05. Dengan demikian disimpulkan bahwa peserta didik di SMP Kristen Luwuk TIDAK SERING menggunakan gadget untuk memperdalam kerohanian mereka.

Dari 46 responden peserta didik SMP Kristen Luwuk yang berpartisipasi dalam penelitian ini, secara umum menyatakan jarang menggunakan gadget untuk memperdalam kerohanian. Responden lebih banyak yang mengaku jarang menggunakan gadget untuk membaca Alkitab, jarang menggunakan gadget untuk mendengarkan lagu-lagu rohani, jarang menggunakan gadget untuk mencari renungan di internet, jarang membaca status-status rohani di media sosial, serta jarang mengikuti akun-akun rohani di media sosial. Hal tersebut dapat dilihat pada tabel 2 - tabel 6 berikut.

Tabel 2. Membaca Alkitab di handphone

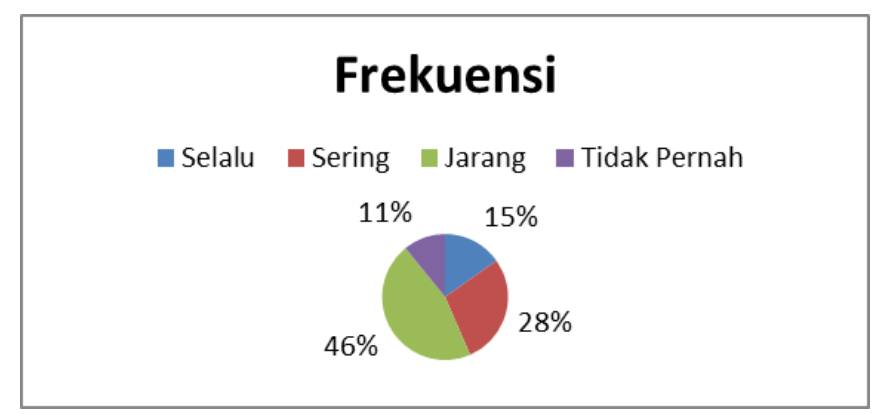

Tabel 3. Mendengarkan lagu-lagu rohani di handphone 
BONAFIDE: Jurnal Teologi dan Pendidikan Kristen

www.jurnal.sttissiau.ac.id/Volume 1/Nomor 1/Juni 2020/hal. 83-101

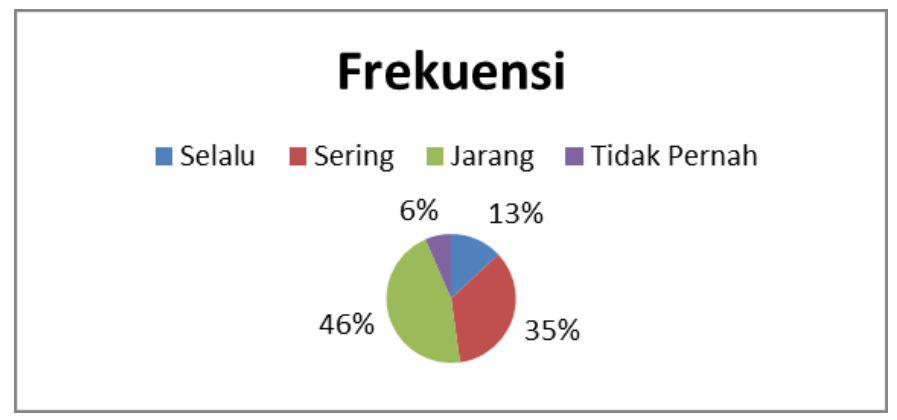

Tabel 4. Mencari renungan di internet

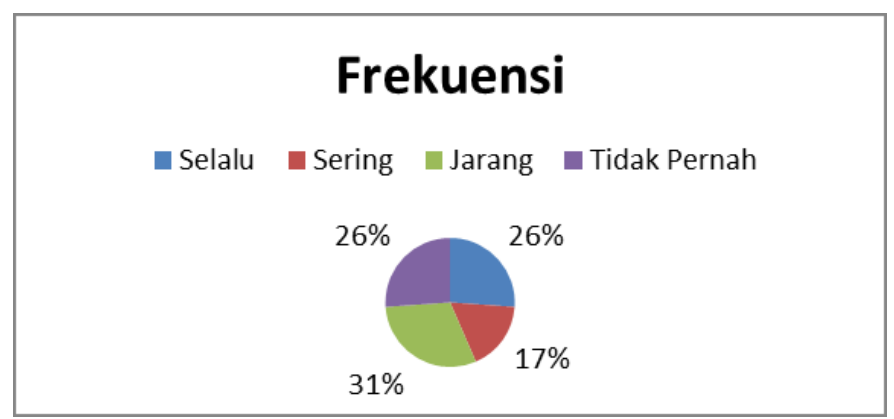

Tabel 5. Membaca status-status rohani di media sosial

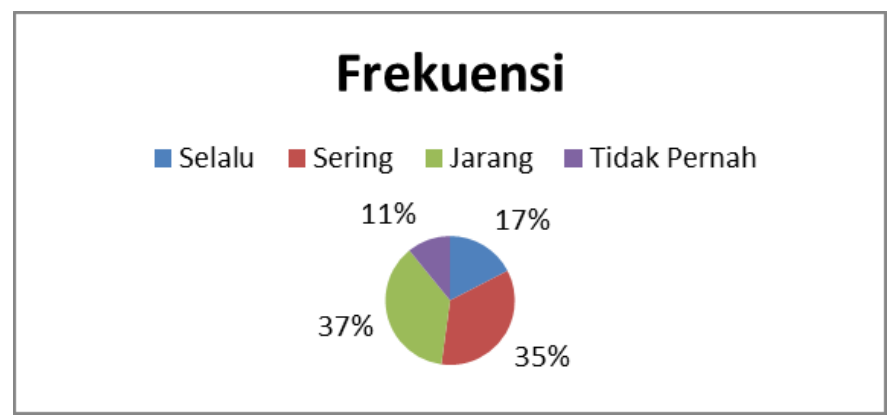

Tabel 6. Mengikuti akun-akun rohani di media sosial

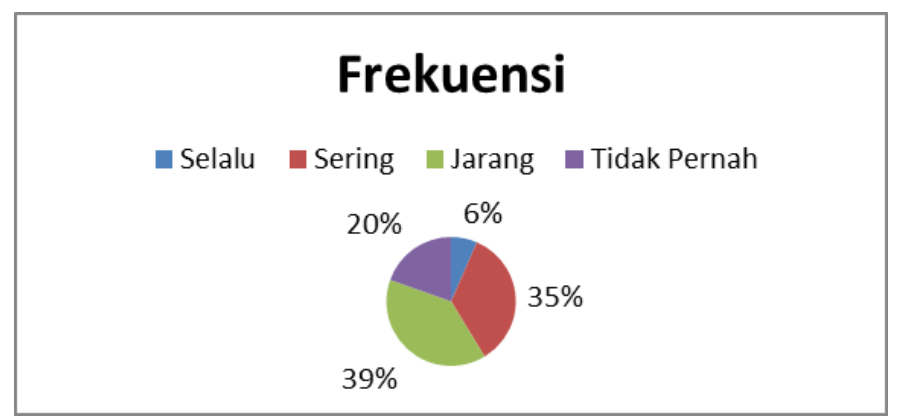




\section{Gadget dalam Pembelajaran PAK di Sekolah}

\section{Wawancara dengan Guru PAK}

Penelitian tahap 2 dilakukan dengan dua tehnik pengembailan data. Pertama mewawancarai guru PAK yang ada di SMP Kristen Luwuk yang hanya berjumlah 1 orang. Kepada informan diajukan 3 pertanyaan: 1) apakah dalam kurikulum pembelajaran PAK yang digunakan di sekolah sudah ada konten mengenai gadget, 2) apakah ada materi mengenai teknologi atau gadget dalam buku-buku yang dijadikan bahan pembelajaran di sekolah, 3) apakah guru PAK pernah menasihati peserta didik untuk menggunakan gadget dengan baik.

Untuk pertanyaan pertama, informan menjawab dengan penjelasan bahwa sebenarnya dalam kurikulum pembelajaran PAK sudah terdapat konten tentang gadget sebab “... kurikulum 2013 disusun pada saat teknologi atau gadget ini sedang sangat dekat dengan kehidupan manusia, termasuk dalam hal penggunaan gadget kepada siswa”.

Untuk pertanyaan kedua, penjelasan informan adalah sebagai berikut:

"Kalau materi itu untuk yang memang membahas secara khusus mengenai gadget untuk sekarang ini tidak ada. Hanya ada beberapa materi yang dikaitkan dengan penggunaan HP atau teknologi lainnya. Contohnya salah satu itu materi mengenai tanggung jawab, kalau tidak salah didapat di kelas IX. Di materi ini bisa dikaitkan dengan penggunaan tekonologi atau gadget."

Untuk pertanyaan ketiga: informan menjawab: "Ya, pernah. Itu memang selalu diingatkan supaya anak-anak ini menggunakan hp dengan hal-hal yang positif. Misalnya mereka mau mengerjakan tugas, carilah tugas di situ karena semua kan ada di situ. Tapi kalau ada hal-hal yang negatif sebaiknya tidak usah ditonton." 
Berdasarkan wawancara ini bisa disimpulkan bahwa materi tentang gadget sudah ada dalam kurikulum pembelajaran PAK dan guru PAK sudah berusaha mengingatkan peserta didik untuk menggunakan gadget secara positif, terutama untuk memperdalam kerohanian. Namun khusus dalam buku-buku yang menjadi materi belajar belum ada materi khusus mengenai gadget.

\section{Studi Dokumen Terhadap Kurikulum 2013}

Meskipun guru PAK yang menjadi informan dalam penelitian ini mengatakan bahwa kurikulum 2013 tentang PAK sudah mengakomodir perihal gadget, namun jika dicermati sebenarnya secara spesifik belum ada. Hal serupa dan terkait dengan gadget hanya tentang tekonologi yang tercantum dalam Kompetensi Inti untuk Kelas VII, VIII, dan IX pada poin 3. Namun dalam uraian di Kompetensi Dasar tidak ada pembahasan mengenai gadget atau teknologi informasi sebagaimana tampak pada tabel berikut. (Kementerian Pendidikan dan Kebudayaan 2012).

Kelas VII

\begin{tabular}{|l|l|}
\hline \multicolumn{1}{|c|}{ Kompetensi Inti } & \multicolumn{1}{c|}{ Kompetensi Dasar } \\
\hline $\begin{array}{l}\text { 3. Memahami pengetahuan (faktual, } \\
\text { konseptual, dan prosedural) }\end{array}$ & 3.1 Mengakui bahwa pemeliharaan \\
berdasarkan rasa ingin tahunya tentang & Allah terhadap manusia dan alam lebih \\
ilmu pengetahuan, teknologi, seni, & untuk merusaknya \\
budaya terkait fenomena dan kejadian & \\
tampak mata & \\
\hline
\end{tabular}


Kelas VIII

\begin{tabular}{|l|l|}
\hline \multicolumn{1}{|c|}{ Kompetensi Inti } & \multicolumn{1}{|c|}{ Kompetensi Dasar } \\
\hline 3. Memahami dan menerapkan & 3.1 Memahami dan mampu \\
pengetahuan (faktual, konseptual, dan & menjelaskan makna hidup bersyukur \\
prosedural) berdasarkan rasa ingin & sebagai orang yang beriman \\
tahunya tentang ilmu pengetahuan, & \\
teknologi, seni, budaya terkait & \\
fenomena dan kejadian tampak mata & \\
\hline
\end{tabular}

\section{Kelas IX}

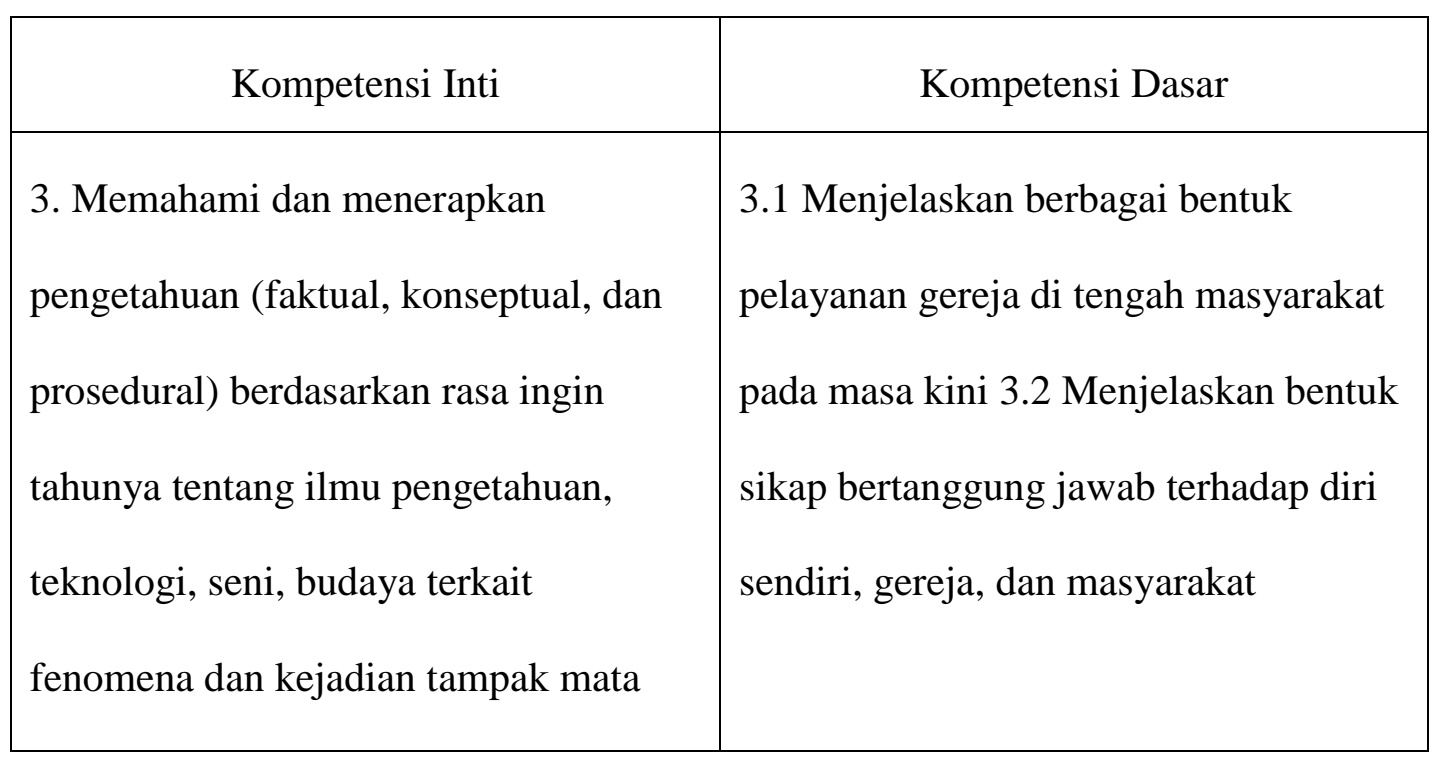

\section{Studi Dokumen Terhadap Buku-buku Pelajaran PAK}

Informan guru PAK mengatakan bahwa materi atau buku pelajaran yang khusus membahas tentang belum ada. Jika merujuk pada buku "Pendidikan Agama Kristen dan Budi Pekerti” untuk kelas VII, VIII, dan IX yang disediakan oleh Pemerintah melalui website BukuSekolahDigital.com, tampak memang 
materi tentang gadget masih sangat sedikit. Hanya ada sedikit bagian yang membicarakan tentang itu yaitu:

1. Materi Kelas VII untuk Siswa pada bagian "Tanggung Jawab Memelihara Alam”, Kegiatan 4: Pendalaman Materi. Isinya tentang sampah gadget. (NonSerrano 2017).

2. Materi Kelas VIII untuk Guru, pada uraian tentang Tantangan di Masa Kini. Bagian 1 tentang Teknologi. Isinya menguraikan sedikit tentang dampak negatif internet. (Chandra dan Non-Serrano 2017).

3. Materi Kelas IX untuk guru, pada bagian tentang Dampak Dunia yang Berubah. Pada bagian ini ada uraian sedikit tentang dampak negatif dan postif teknologi informasi. (Depdikbud RI 2015).

Hal ini memperkuat penjelasan informan pada bagian wawancara bahwa materi khusus mengenai gadget dalam buku-buku pelajaran yang digunakan di sekolah memang belum ada.

\section{PEMBAHASAN}

Para siswa SMP Kristen Luwuk belum menggunakan gadget untuk memperdalam kerohanian mereka. Artinya mereka belum memanfaatkan aspek positif dari gadget. PAK sebagai mata pelajaran yang bertujuan untuk mempertemukan antara iman Kristen dengan kehidupan sehari-hari mereka belum mengondisikan para siswa memanfaatkan gadget untuk memperdalam kerohanian mereka. Hal tersebut terjadi karena beberapa hal berikut. 
Pertama, porsi gadget masih sedikit dalam kurikulum 2013 yang digunakan di SMP Kristen Luwuk. Jika mengacu pada Undang-undang No. 2 tahun 1989 tentang Sistem Pendidikan Nasional, pada pasal 1 ayat 9 disebutkan bahwa kurikulum merupakan "pedoman penyelenggaraan kegiatan belajarmengajar" (Depdikbud RI 1989). Artinya, jika gadget belum dibicarakan dalam kurikulum PAK atau porsinya masih sangat sedikit, maka sangat besar kemungkinan dalam buku-buku pelajaran di sekolah maupun proses belajar yang dipandu oleh guru PAK juga akan sangat sedikit berbicara mengenai gadget.

Kedua, materi tentang gadget dalam buku-buku pelajaran PAK di sekolah masih minim. Guru PAK dalam yang menjadi informan dalam penelitian ini mengatakan belum adanya panduan khusus mengenai gadget dalam pembelajaran PAK. Tampaknya ini menunjukkan bahwa para pakar PAK di Indonesia yang memiliki kapasitas dan otoritas untuk membuat buku-buku pelajaran PAK di sekolah belum banyak yang memberi perhatian khusus kepada integrasi gadget ke dalam PAK.

Ketiga, peran guru PAK sebagai pengembang kurikulum belum berjalan maksimal. Dalam manajemen pembelajaran di sekolah seorang guru dituntut melaksanakan kegiatan belajar mengajar berdasarkan pada kurikulum yang berlaku secara nasional. Namun seperti dikemukakan oleh Nur bahwa guru sebenarnya adalah pengembang kurikulum. Beliau mengutip Sukmadinata yang mengatakan bahwa "implementasi kurikulum di sekolah hampir seluruhnya tergantung pada kreativitas, kecakapan, kesungguhan, dan ketekunan guru." Sebagai pengembang kurikulum, guru menerjemahkan, menjabarkan, dan 
mentransformasikan nilai-nilai yang terdapat dalam kurikulum kepada peserta didik. (Nur 2011). Octavian menyebutkan guru sebagai "kurikulum yang hidup dan berjalan”. Kurikulum merupakan benda mati yang harus dihidupkan oleh guru. (Oktavian 2018).

Di SMP Kristen Luwuk tampaknya guru masih berpatokan pada kurikulum dan materi pembelajaran yang terbatas. Informan hanya mengaku "pernah" dan "selalu" mengingatkan peserta didik untuk menggunakan gadget secara positif. Upaya seperti ini tentu belum menjadikan gadget sebagai bagian dari proses pembelajaran. Apalagi informan berpendapat bahwa penggunaan gadget oleh peserta didik secara positif "tergantung pada pemakai, mau menggunakan secara positif atau negatif."

Dalam kaitan dengan moral anak, Sari mengemukakan guru dengan "label" Kristen memiliki tanggung jawab yang besar terhadap moral anak untuk mengarahkannya sesuai dengan nilai-nilai Kristen. (Sari 2019). Apalagi dalam hal kerohanian, guru PAK memiliki tanggung jawab yang lebih besar. Salah satu potensi yang bisa dimanfaatkan adalah penggunaan gadget.

\section{KESIMPULAN}

Temuan dari penelitian ini adalah bahwa di SMP Kristen Luwuk, PAK belum memberi pengaruh kepada penggunaan gadget untuk memperdalam kerohanian di kalangan peserta didik. Hal ini disebabkan antara lain gadget belum mendapat porsi yang signifkan dalam kurikulum PAK yang digunakan, masih sedikit dalam buku-buku pelajaran yang dijadikan acuan, dan guru belum memainkan peran strategis sebagai pengembang kurikulum. 
BONAFIDE: Jurnal Teologi dan Pendidikan Kristen

www.jurnal.sttissiau.ac.id/Volume 1/Nomor 1/Juni 2020/hal. 83-101

Semua ini tampaknya disebabkan gadget sesungguhnya belum terlalu menjadi perhatian stakeholder pelaksanaan PAK di sekolah, mulai dari pembuat kurikulum, penulis buku-buku pelajaran, hingga guru-guru PAK di sekolah. Gadget umumnya masih dilihat sebatas fungsinya sebagai alat komunikasi dan untuk mencari hiburan. Padahal dalam perkembangan dewasa ini gadget telah menginvasi budaya manusia dan menciptakan trend penggunaan gadget secara masif, termasuk di kalangan remaja.

Hilda Thaba, seorang pakar kurikulum, menyebutkan kriteria kurikulum yang baik antara lain: isinya berpegang kepada kenyataan-kenyataan sosial, dapat dipelajari dan disesuaikan dengan pengalaman siswa. (Hernawan dan Andriyani 2011). Kenyataan sosial dan pengalaman para siswa di mana mereka telah menjadi pengguna gadget secara aktif, mestinya menjadi bahan pertimbangan penting dalam penyelenggaraan PAK di sekolah.

\section{DAFTAR PUSTAKA}

Anwar, Fahmi. 2017. "Perubahan dan Permasalahan Media Sosial.” Jurnal Muara Ilmu Sosial, Humaniora, dan Seni 1 (1): 137. https://doi.org/10.24912/ jmishumsen.v1i1.343.

APJII. 2018. "Hasil Survei Penetrasi dan Perilaku Pengguna Internet Indonesia 2018." https://www.apjii.or.id/. 2018. https://www.apjii.or.id/content/read/ 39/410/Hasil-Survei-Penetrasi-dan-Perilaku-Pengguna-Internet-Indonesia2018.

Chandra, Julia Suleeman, dan Janse Belandina Non-Serrano. 2017. Pendidikan Agama Kristen untuk Kelas VIII: Buku Guru. Jakarta: Kementerian Pendidikan dan Kebudayaan. http://bsd.pendidikan.id/data/2013/ kelas_8smp/guru/Kelas_08_SMP_Pendidikan_Agama_Kristen_dan_Budi_P ekerti_Guru_2017.pdf.

Chusna, Puji Asmaul. 2017. "Pengaruh Media Gadget Para Perkembangan Karakter Anak.” Dinamika 17 (2): 315-30. 
BONAFIDE: Jurnal Teologi dan Pendidikan Kristen

www.jurnal.sttissiau.ac.id/Volume 1/Nomor 1/Juni 2020/hal. 83-101

Creswell, John W. 2016. Research Design Pendekatan Kualitatif, Kuantitatif, dan Mixed. Yogyakarta: Pustaka Pelajar.

Depdikbud RI. 1989. “Undang-undang Republik Indonesia No. 2 Tahun 1989 tentang Sistem Pendidikan Nasional dan Penjelasannya."

. 2015. Pendidikan Agama Kristen dan Budi Pekerti Kelas IX: Buku Guru. Jakarta: Kementerian Pendidikan dan Kebudayaan. http://bsd.pendidikan.id/ data/2013/kelas_9smp/guru/Kelas_09_SMP_Pendidikan_Agama_Kristen_da n_Budi_Pekerti_Guru.pdf.

Gultom, Andar. 2008. Pendidikan Agama Kristen. Jakarta: Engkateia Putra Jaya.

Hernawan, Asep Herry, dan Dewi Andriyani. 2011. "Hakikat Kurikulum dan Pembelajaran." In Pengembangan Kurikulum dan Pembelajaran EKOP.

Juwita, Elsa Puji, Dasim Budimansyah, dan Siti Nurbayani. 2015. "PERAN MEDIA SOSIAL TERHADAP GAYA HIDUP SISWA.” SOSIETAS 5 (1). https://doi.org/10.17509/sosietas.v5i1.1513.

Kementerian Pendidikan dan Kebudayaan. 2012. Kurikulum 2013.

Marpaung, Junierissa. 2018. "PENGARUH PENGGUNAAN GADGET DALAM KEHIDUPAN." KOPASTA: Jurnal Program Studi Bimbingan Konseling 5 (2). https://doi.org/10.33373/kop.v5i2.1521.

Non-Serrano, Janse Belandina. 2017. Pendidikan Agama Kristen dan Budi Pekerti untuk Kelas VII. Jakarta: Kementerian Pendidikan dan Kebudayaan. http://bsd.pendidikan.id/data/2013/kelas_7smp/siswa/Kelas_07_SMP_Pendid ikan_Agama_Kristen_dan_Budi_Pekerti_Siswa_2017.pdf.

Nur, Azhar M. 2011. "TUGAS GURU SEBAGAI PENGEMBANG KURIKULUM.” DIDAKTIKA XII (1): 59-67.

Oktavian, Catur. 2018. "KURIKULUM DAN GURU." suaraguruonline.com. 2018. http://suaraguruonline.com/kurikulum-dan-guru/.

Pailang, Herianto Sande, dan Ivone Bonyadone Palar. 2012. "Membangun Spiritual Remaja Masa Kini Berdasarkan Amsal 22: 6." Jurnal Jaffray 10 (1): 59-86. https://doi.org/10.25278/jj71.v10i1.63.

Posumah-Santoso, Jedidah T. 2006. "Pendidikan Agama Kristen di Sekolah: Suatu Bidang Ilmu Asuhan Iman Kristen.” In Ajarlah Mereka Melakukan, 152-64. Jakarta: BPK Gunung Mulia.

Saputro, Khamim Zarkasih. 2018. "Memahami Ciri dan Tugas Perkembangan Masa Remaja.” Aplikasia: Jurnal Aplikasi Ilmu-ilmu Agama 17 (1): 25-32. https://doi.org/10.14421/aplikasia.v17i1.1362.

Yani Margaretha Molawan, Ermin Alperiana Mosooli 100 
BONAFIDE: Jurnal Teologi dan Pendidikan Kristen

www.jurnal.sttissiau.ac.id/Volume 1/Nomor 1/Juni 2020/hal. 83-101

Sari, Dwi Novita. 2019. "UPAYA PREVENTIF GURU KRISTEN DALAM MENGHADAPI DEGRADASI MORAL ANAK." Visio Dei: Jurnal Teologi Kristen 1 (1): 79-100. http://jurnal.sttstarslub.ac.id/index.php/ js/article/view/11.

Sugiyono. 2015. Metode Penelitian Kombinasi (Mixed Methods). Bandung: Alfabeta.

2018. Metode Penelitian Kuantitatif, Kualitatif, dan R\&D. Bandung: Alfabeta.

Tani, Friska, Antonius Boham, dan Pingkan Tangkudung. 2016. "KAJIAN PERAN MEDIA ONLINE BAGI PEMUDA DI GEREJA ADVENT WALANTAKAN KECAMATAN LANGOWAN BARAT." Acta Diurna 5 (3). 